\title{
Small-scale disturbance and increased nutrients as influences on intertidal macrobenthic assemblages: experimental burial of wrack in different intertidal environments
}

\author{
F. Rossi* , A. J. Underwood \\ Centre for Research on Ecological Impacts of Coastal Cities, Marine Ecology Laboratories A11, Science Road, \\ University of Sydney, New South Wales 2006, Australia
}

\begin{abstract}
Wrack (dead, washed-up seaweed and seagrass) buried in soft substrata causes increased organic content and alters the physical structure of sediments. These effects may influence the types and relative abundances of species in the sediment. Such influences can be expected to vary according to the type and organic content of the sediment. In this study, wrack was buried in 3 mudflats and 2 intertidal sandflats (with coarser sediments) in Botany Bay (New South Wales, Australia). The experiments tested the hypotheses that burial of wrack would (1) increase the content of total nitrogen (N) and organic carbon (OC) of sediments; (2) increase the biomass of micro-algae; and (3) alter the abundances of macrofauna in the sediments. Simulated wrack (equivalent amounts of plastic ribbon, without any organic content) was added to other experimental plots to test the above hypotheses when only physical disturbance, not organic enrichment, occurred. Total OC, N and chlorophyll a (chl a) were sampled every $2 \mathrm{wk}$ for $6 \mathrm{wk}$ and macrofauna were sampled after 6 wk. Some taxa (capitellid, orbinid and nereid worms) increased abundances where wrack was added. Nereidae, however, responded only in muddy sediments. The physical structure associated with wrack also caused an increase in numbers of Oligochaeta and increased patchiness in numbers of the soldier-crab Mictyris longicarpus, but only in sites where they were already abundant. Wrack represents a source of food for some taxa. Physical disturbance due to burial of wrack also adds to patchiness and abundance of taxa on sandy and muddy intertidal shores. The major responses of fauna predicted from other studies did not occur.
\end{abstract}

KEY WORDS: Botany Bay $\cdot$ Buried wrack $\cdot$ Disturbance $\cdot$ Macrofauna $\cdot$ Nutrients

Resale or republication not permitted without written consent of the publisher

\section{INTRODUCTION}

In many shallow water marine habitats, a major natural disturbance is the stranding of mats of dead plant material, called wrack. In intertidal habitats, wrack is deposited throughout the entire intertidal range, but lower on a shore, mats of wrack are moved about by tides and waves. At higher tidal levels and in more sheltered areas, however, wrack may stay on the

*E-mail: frossi@bio.usyd.edu.au bottom for some months (Hull 1987, Valiela \& Rietsma 1995) and often, mats are buried in the sediments (Ford et al. 1999).

Dead plants deposited on the shore will affect the physical and chemical characteristics of the sediments (Raffaelli et al. 1998). Drift algae and seagrasses alter the structure of habitats, for example, by providing refuges (Holmquist 1997, Norkko et al. 2000). Decomposition of the plants releases nutrients into the sediment, stimulating the growth of bacteria and modifying the concentration of oxygen (Harrison \& Mann 1975, Rice \& Tenore 1981, Levinton et al. 1984, Pel- 
likaan 1984, Tenore et al. 1984). The wrack washed up on a beach can be buried by sediment, sometimes after a period of decomposition on the surface. Buried wrack will decay, releasing nutrients, particularly $\mathrm{N}$ and $\mathrm{P}$, which can enhance reproduction of benthic microalgae (Dizon \& Yap 1999, Posey et al. 1999), stimulate growth of aerobic and anaerobic bacteria as well as reducing exchange of oxygen with the sediment (Raffaelli et al. 1991, 1998, Sundback et al. 1996, Norkko et al. 2000). Anaerobic decomposition of buried wrack may occur (Harrison 1989), with quite different outcomes from those due to degradation of wrack on the surface of sediments. The processes are complex and will depend on the amount and taxonomic composition of the wrack as well as on the temporal frequency and spatial distribution of its deposition (Valiela et al. 1997, Raffaelli et al. 1998).

On sandy beaches and mudflats, deposition and subsequent burial of wrack is usually at small scales, creating a mosaic of bare and wrack-affected areas. Shapes and extent of the patches and the thickness of the mats can be extremely variable with a range of approximately 0.1 to $1 \mathrm{~m}^{2}$ and 1 to $5 \mathrm{~cm}$, respectively (Valiela \& Rietsma 1995).

Infaunal organisms in soft sediments are often distributed in temporal and spatial mosaics of patches at a number of different scales (e.g. Thrush 1991, Azovsky et al. 2000). Disturbances cause temporal and spatial heterogeneity by killing, displacing or damaging organisms and by creating opportunities for establishment of others (Dayton 1971, Paine \& Levin 1981, Sousa 1984, Pickett et al. 1989, Underwood 1989, Valiela \& Rietsma 1995, Ford et al. 1999). Therefore, disturbances influence the structure and function of animal assemblages and determine taxonomic composition, number and turnover of species in marine assemblages (Valiela \& Rietsma 1995). In addition to the frequency, intensity and scale of disturbance, the responses of populations are determined by their inertia, resilience and stability (e.g. Underwood 1989, Norkko \& Bonsdorff 1996a,b, Baldwin \& Mendelssohn 1998).

Disturbances to plants and animals due to detritus have been studied with regard to the increased amounts of seaweed produced by eutrophication (Hull 1987, Raffaelli et al. 1991, Norkko \& Bonsdorff 1996a,b, Valiela et al. 1997, Ford et al. 1999, Renaud et al. 1999). There have, however, been few field studies of deposition of wrack, which is a natural disturbance (Valiela \& Rietsma 1995, Baldwin \& Mendelssohn 1998, Brewer et al. 1998, Colombini et al. 2000). Most of the studies of the impact of wrack and seaweeds have been done on mats on the surface of sediments (Ford et al. 1999). The effect of buried algal/seagrass mats has received only incidental documentation (Hull 1987, Ford et al. 1999), despite their importance in macrofaunal and detrital food webs.

In addition, most studies of responses of organisms to organic enrichment of detritus have been done in fine sediments, which are often rich in organic material (Webb 1996). Little is known of the response of animals living in sands with little organic content. Tolerance of animals in sandy sediments to organic enrichment caused by the wrack is likely to be different.

In this paper, we used experimental burial of wrack to test hypotheses about influences on macrofaunal assemblages in intertidal estuarine mud- and sandflats. We predicted that wrack buried in sediments would (1) increase the content of total nitrogen (N) and organic carbon (OC) of the sediment; (2) increase the biomass of benthic micro-algae; and (3) as a result, macrofaunal assemblages would change in their composition and in relative abundances of taxa. Furthermore, we predicted that responses would differ in sandy sediments from those in muddy sediments because the former naturally have less organic content. Finally, it has sometimes been concluded that disturbances increase variability in ecological measures (Warwick \& Clarke 1993), although this is clearly not always the case and variance can be decreased by disturbance (Chapman et al. 1995). We therefore tested the hypothesis that wrack or physical disturbance would alter the variances in experimental treatments.

\section{MATERIALS AND METHODS}

Study areas. Experiments were done in Botany Bay, NSW, Australia (Fig. 1), on 5 sheltered intertidal flats which were completely exposed during low tides. Sites 1 to 3 (Fig. 1) were mudflats (sizes of particles ranging between $0.63 \mu \mathrm{m}$ and $0.5 \mathrm{~mm}$ ) with a mean $( \pm \mathrm{SE})$ content of OC $(\%)$ of $0.11(0.07), 0.25(0.03)$ and 0.11 (0.01), respectively. Sites 4 and 5 (Fig. 1) were sandy (with particles ranging between 0.5 and $1 \mathrm{~mm}$ ) with an OC content of $0.08(0.01)$ and 0.06 (0.01). Data are from 2 dates of sampling and are an average of 20 measures. Originally, there were 3 sandflats, but the experiments in the third site were damaged by nearby construction.

Experimental design. Manipulative experiments were started in each of the 5 sites on 19 and 20 March 2001. During low tide, 3 treatments were established in each site: addition of wrack (W), procedural control for the structure of the wrack (PC) and natural control (C). At each site, 15 randomly chosen plots $(50 \times 50 \mathrm{~cm}) 1$ to $2 \mathrm{~m}$ apart were chosen. Five plots were randomly assigned to each treatment. Positions of plots were marked by a stake and were measured from 3 fixed reference points so that plots could be relocated. 
Detrital wrack was collected on intertidal areas around the study sites. Wrack was mainly composed of the seagrass Zostera capricornii and red seaweeds, which were too decomposed to be classified. In the laboratory, wrack was washed and refrigerated $\left(-20^{\circ} \mathrm{C}\right)$ for at least $24 \mathrm{~h}$ to kill any organisms. No chlorophyll $a$ (chl a) was present in the wrack when it was collected (this was examined spectrophotometrically).

In experimental plots (W), $1.2 \mathrm{~kg}$ wet wt of wrack was buried in the sediment at a depth of about $5 \mathrm{~cm}$. The sediment was removed from the surface by sliding a thin layer of stiff PVC into the sediment and lifting it with the sediment on its top. This scarcely disturbed the sediment. Then wrack was spread evenly in the plot (thickness about $2 \mathrm{~cm}$ ) and the sediment removed was added. In this way, horizontal and vertical mixing of sediment was prevented. In addition to potential enrichment of nutrients, wrack causes physical, structural changes to habitat. To examine this and to check for disturbance to the sediment by the wrack (procedural control, PC), plastic ribbons of similar size, shape and cover to the wrack were buried in sediments. Control plots (C) were disturbed and sediment replaced without adding anything.

Three times, approximately every $2 \mathrm{wk}$, all sites were sampled for OC, $\mathrm{N}$ and chl a. Two replicate cores of sediment ( $2.5 \mathrm{~cm}$ internal diameter) were taken from each plot. At the end of the experiment (6 wk after the addition of wrack, 4 and 5 May 2001), 2 replicate cores (10 $\mathrm{cm}$ internal diameter) were taken to sample the macrofauna. A 6 wk period was chosen because previ-

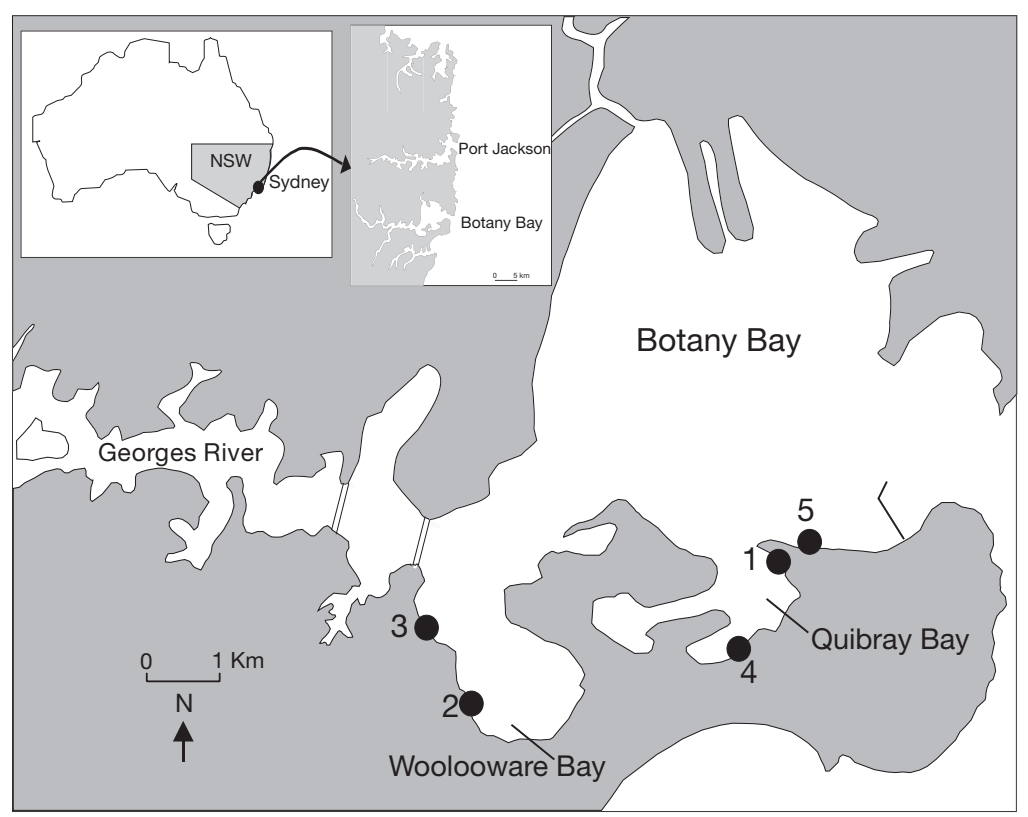

Fig. 1. Location of study sites in Botany Bay. Sites 1, 2 and 3 are mud flats (Mud 1, 2 and 3) and Sites 4 and 5 are sand flats (Sand 4 and 5) ous studies suggested that effects on macrofauna of seaweeds on the surface would occur in 2 to $10 \mathrm{wk}$ (Thrush 1986, Hull 1987, Norkko \& Bonsdorff 1996a,b, Bolam et al. 2000). Furthermore, buried material would decay quickly, so experiments could not be longer.

Macrofaunal samples were collected to a depth of $8 \mathrm{~cm}$ (i.e. slightly below the layer of wrack where the wrack was present). In the laboratory, sediment was elutriated 15 times and the supernatant sieved at 0.5 $\mathrm{mm}$. The number of times of elutriation was determined by searching for animals in sediment of 30 samples from different sites after different amounts of elutriation. All macrofaunal samples were fixed in $4 \%$ buffered formalin, sorted, and animals were counted and identified to family level, when possible.

Sediment for total OC, $\mathrm{N}$ and chl a was collected at the same depth of macrofauna samples using plastic corers of $2.5 \mathrm{~cm}$ inner diameter. Samples were placed in plastic bags, kept in the dark and frozen at $-20^{\circ} \mathrm{C}$ within $3 \mathrm{~h}$. In the laboratory, all wrack in samples was removed by hand. Samples were homogenised and sub-samples of about $3 \mathrm{~g}$ wet wt were taken. Chl a was extracted according to Plante-Cuny (1974) in darkness for $24 \mathrm{~h}$ at 0 to $4^{\circ} \mathrm{C}$ using a $90 \%$ acetone solution. Pigments were measured spectrophotometrically before and after treatment with $0.1 \mathrm{~N} \mathrm{HCl}$. Precombusted $\left(450^{\circ} \mathrm{C}\right.$ for $\left.3 \mathrm{~h}\right)$ sediment was used as a blank. In addition, the content of phaeopigments was measured to check for any pigments introduced with wrack; no significant differences were found between the plots to which wrack was added and the controls.

The sediment for analyses of total OC and $\mathrm{N}$ was desiccated at $60^{\circ} \mathrm{C}$ overnight. Inorganic carbon was removed by aqueous acidification of $0.1 \mathrm{~N} \mathrm{HCl}$, following the method of Hedges \& Stern (1984). Measurements were made using a Perkin-Elmer CHN element analyser.

Analyses of data. Changes in macrofaunal assemblages were analysed at each site separately using a 2-factor orthogonal non-parametric analysis, N-P MANOVA (Anderson 2001) with a posteriori multiple comparisons, based on Bray-Curtis (dis)similarity measures. Non-metric multi-dimensional scaling (nMDS) was used to plot the rank-order differences among treatments based on Bray-Curtis distances in each site. Taxa that mostly contributed to the dissimilarity/similarity among/within treatments and sites were identified using SIMPER analysis (Clarke 1993).

Changes in the content of total chl $a$, $\mathrm{OC}$ and $\mathrm{N}$, and in the abundance of the 
main representative taxa were investigated using a 3factor mixed model analysis of variance. Treatments (3 levels), Sites (5 levels) and Plots (5 levels) were factors. Treatments was fixed, Sites was random and orthogonal to treatment, and Plots was random and nested in the interaction Treatments $\times$ Sites. Any interaction or nested component that was sufficiently small with a probability $\geq 0.25$ was pooled (Winer et al. 1991). Before analysis, the homogeneity of variances was evaluated by using Cochran's test (Winer et al. 1991). All data were $\log (x+1)$-transformed.

Multiple comparisons for total OC, $\mathrm{N}$ and chl a were analysed using a priori tests at $\mathrm{p}=0.05$ (Underwood 1997). Comparisons between $C$ and $P C$ were made as the first step. When they did not differ from each other, their mean was compared to that of $\mathrm{W}$, to test the hypothesis that this treatment had a greater content of total OC, N or chl a than the other two. To analyse the macrofauna, a posteriori multiple comparisons were done using SNK tests (Underwood 1997). Analyses of variance, Cochran's test and SNK tests were done using GMAV 5 (A. J. Underwood \& M. G. Chapman unpubl.).

Additionally, differences among treatments were analysed using Anderson's (1959) test to identify nonrandom patterns in the rank order of mean values of variables across the 3 treatments.

The variation among replicates was also analysed, to test the hypothesis that disturbance caused changes in variance. Differences among treatments of the residual variance were analysed by a 2-way mixed model of analysis of variance with Treatment (fixed) and Site (random) as orthogonal factors. Five replicates were used (i.e. the variance among replicates calculated from each plot of each treatment). Variances were logtransformed before analysis.

\section{RESULTS}

\section{Analyses of total $\mathrm{OC}, \mathrm{N}$ and $\mathrm{chl}$ a}

In general, there was more $\mathrm{OC}$ and $\mathrm{N}$ in experimental treatments (W in Fig. 2a,b) than in controls. This occurred more often than by chance for week 2 (Anderson's test; $Q^{2}=11.4, \mathrm{p}<0.05$ ). The analyses of variance were generally not significant (analyses in Table 1), except for increased carbon in plots with wrack compared with controls in Sites 3 and 4 after $2 \mathrm{wk}$ and at Sites 2, 3 and 4 after $4 \mathrm{wk}$. As a result, there were interactions between Sites and Treatments in analyses at 2 and $4 \mathrm{wk}$.

The increased amount of $\mathrm{N}$ was statistically significant only for Site 3 after 2 and 4 wk and at Site 2 after 6 wk (analyses in Table 1 and a priori test, $\mathrm{p}<0.017$ ). It was particularly noticeable that the sandy sites (Sites 4 and 5) had very little $\mathrm{N}$ in the sediments. This was par-

Table 1. ANOVAs of content of organic carbon (OC), nitrogen $(\mathrm{N})$ and chlorophyll a $(\mathrm{chl} \mathrm{a})\left(\mu \mathrm{g} \mathrm{g} \mathrm{g}^{-1}\right)$ at each time of sampling. Treatments (T) (addition of wrack [W], procedural control for the structure of the wrack [PC] and natural control [C]) are fixed factors; Sites (S) and Plots (P) within each $\mathrm{T}$ and $\mathrm{S}$ are random. ns = not significant

\begin{tabular}{|c|c|c|c|c|c|c|c|c|c|c|c|}
\hline \multirow[b]{2}{*}{ OC } & \multirow[b]{2}{*}{ Source } & \multirow[b]{2}{*}{$\mathrm{df}$} & \multicolumn{3}{|c|}{$-2 \mathrm{wk} \longrightarrow$} & \multicolumn{3}{|c|}{$-4 \mathrm{wk} \longrightarrow$} & \multicolumn{3}{|c|}{$-6 \mathrm{wk}-$} \\
\hline & & & MS & $F$ & $\mathrm{p}$ & MS & $F$ & $\mathrm{p}$ & MS & F & $\mathrm{p}$ \\
\hline $\mathrm{T}$ & & 2 & 0.043 & 5.23 & $<0.05$ & 0.066 & 5.95 & $<0.05$ & 0.025 & 2.17 & ns \\
\hline $\mathrm{S}$ & & 4 & 0.097 & 28.41 & $<0.00$ & 0.093 & 18.83 & $<0.00$ & 0.126 & 5.83 & $<0.01$ \\
\hline $\mathrm{T} \times \mathrm{S}$ & & 8 & 0.008 & 2.41 & $<0.05$ & 0.011 & 2.23 & $<0.05$ & 0.011 & 1.44 & ns \\
\hline $\mathrm{P}(\mathrm{T} \times \mathrm{S})$ & & 60 & 0.004 & & $>0.25$ & 0.005 & 2.01 & $<0.01$ & 0.008 & 1.24 & ns \\
\hline Residua & & 75 & 0.003 & & & 0.003 & & & 0.060 & & \\
\hline Pooled $^{a}$ & & 135 & 0.003 & & & - & & & - & & \\
\hline $\mathbf{N}$ & Source & df & $\mathrm{MS} \times 10^{4}$ & $F$ & $\mathrm{p}$ & $\mathrm{MS} \times 10^{4}$ & $F$ & $\mathrm{p}$ & $\mathrm{MS} \times 10^{4}$ & F & $\mathrm{p}$ \\
\hline $\mathrm{T}$ & & 2 & 1.000 & 0.46 & ns & 12.500 & 2.88 & ns & 5.000 & 0.23 & ns \\
\hline $\mathrm{S}$ & & 4 & 18.750 & 19.00 & $<0.001$ & 8.750 & 7.63 & $<0.001$ & 1.250 & 0.50 & ns \\
\hline $\mathrm{T} \times \mathrm{S}$ & & 8 & 2.625 & 3.00 & $<0.01$ & 4.375 & 3.79 & $<0.001$ & 22.000 & 11.00 & $<0.01$ \\
\hline $\mathrm{P}(\mathrm{T} \times \mathrm{S})$ & & 60 & 1.217 & & $>0.25$ & 1.150 & 2.58 & $<0.001$ & 1.633 & & $>0.25$ \\
\hline Residua & & 75 & 1.227 & & & 0.440 & & & 1.506 & & \\
\hline Pooled $^{a}$ & & 135 & 1.222 & & & - & & & 1.563 & & \\
\hline Chl a & Source & $\mathrm{df}$ & MS & $F$ & $\mathrm{p}$ & MS & $F$ & $\mathrm{p}$ & MS & $F$ & $\mathrm{p}$ \\
\hline $\mathrm{T}$ & & 2 & 1.869 & 16.10 & $<0.00$ & 3.411 & 22.74 & $<0.00$ & 1.687 & 5.05 & $<0.05$ \\
\hline S & & 4 & 2.781 & 40.16 & $<0.00$ & 3.358 & 22.38 & $<0.00$ & 3.082 & 31.88 & $<0.00$ \\
\hline $\mathrm{T} \times \mathrm{S}^{\mathrm{a}}$ & & 8 & 0.116 & 1.68 & ns & 0.128 & 0.86 & $>0.25$ & 0.334 & 3.45 & $<0.01$ \\
\hline $\mathrm{P}(\mathrm{T} \times \mathrm{S})$ & & 60 & 0.069 & 1.52 & $<0.05$ & 0.153 & 1.79 & $<0.01$ & 0.097 & 1.35 & ns \\
\hline Residua & & 75 & 0.046 & & & 0.086 & & & 0.072 & & \\
\hline Pooled $^{a}$ & & 68 & - & & & 0.150 & 1.75 & $<0.01$ & - & & \\
\hline
\end{tabular}




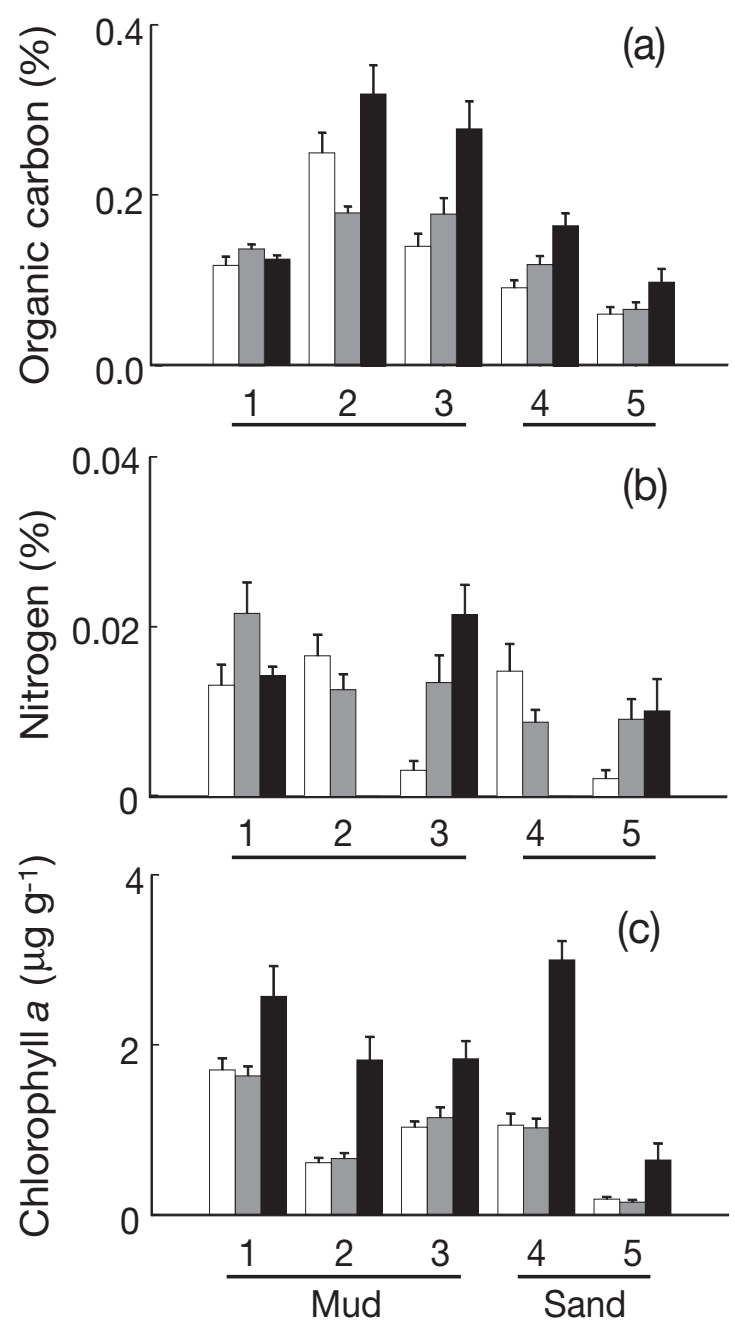

Fig. 2. Mean ( $\pm \mathrm{SE}_{i} \mathrm{n}=30$ ) amounts of (a) organic carbon, (b) total nitrogen and (c) chlorophyll $a$ in the 5 sites, averaged from 2 replicates in each of the 5 plots over 3 times of sampling. $\square=$ controls (C); $\square=$ disturbance controls (PC); and

- experimental addition of wrack (W)

ticularly the case for Site 5, where most samples contained no detectable N (Fig. 2b).

$\mathrm{Chl} a_{\text {, in }}$ contrast, was in greater concentrations in the experimental plots with wrack in all sites at all times (Fig. 2c) and in significantly greater concentrations than in the disturbance controls at most sites and times (all sites at Weeks 2 and 4, in Sites 2, 3 and 4 at Week 6, a total of 13 of the 15 cases analysed; Table 1; a priori test, $\mathrm{p}<0.017$; Anderson's test, $Q^{2}=27.6$, $\mathrm{p}<0.05$ ). The increases were from about 30 to $50 \%$ of values in controls. Thus, experimental manipulation increased the concentrations of chl $a$. There was no increase in phaeopigments (data and analyses not shown here), therefore the extra chl a was not some artefact of the introduction of wrack.

\section{Analyses of assemblages}

There was some evidence to support the hypothesis that assemblages altered in response to addition of nutrients (Fig. 3, Table 2). The assemblages where wrack was added differed from those in controls in Sites 1, 4 and 5 (Table 2). In Site 1, there was a clear difference between the plots with added wrack and the controls, but no clear alternative hypothesis could be defined because the disturbance controls (PC) did not differ from either C or W (Table 2). In Site 4, the assemblages in control plots differed from those where there was wrack ( $\mathrm{C}$ vs $\mathrm{W}$ in Table 2), but also from those in the disturbance controls (PC vs C for Site 4 in Table 2). The wrack and disturbance controls did not differ. It is therefore impossible to attribute the difference to increased nutrients. In Site 5, this difference was not really attributable to some greater dissimilarity between the treatment with wrack and the control, but rather to the smaller variability among plots in the controls (see dissimilarities within $\mathrm{C}$ and $\mathrm{W}$, and between $\mathrm{C}$ and $\mathrm{W}$ in Site 5; Table 2).
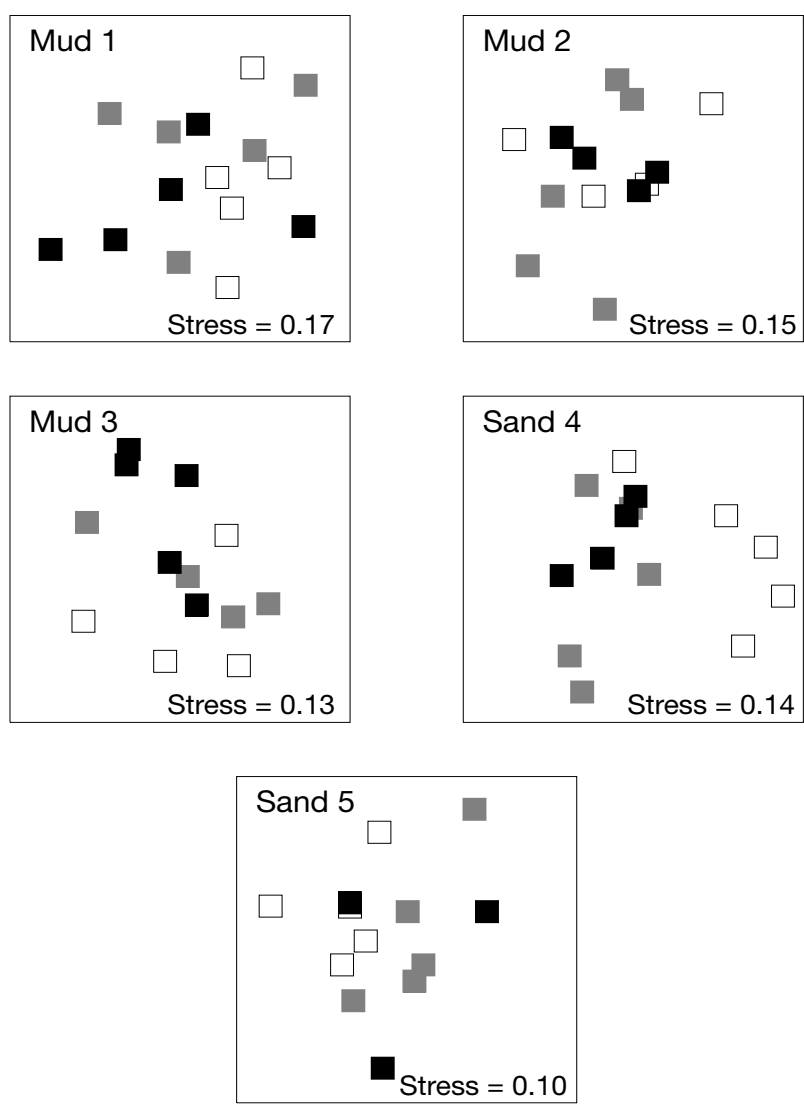

Fig. 3. Non-metric multi-dimensional scaling (nMDS) for differences in assemblages among the treatments in each site; data are centroid for each of 2 replicates. $\square$ : controls (C); $\square$ : disturbance controls (PC); and $\mathbf{\square}$ : addition of wrack (W) 
Table 2. Mean Bray-Curtis dissimilarities (\%) within and between experimental treatments (control [C], disturbance control [PC] and addition of wrack $[\mathrm{W}]$ ); $\mathrm{p}$ indicates significant pairwise comparisons from N-P MANOVA

\begin{tabular}{|c|c|c|c|c|c|}
\hline & \multicolumn{2}{|c|}{$\begin{array}{l}\text { Dissimilarity (\%) } \\
\text { among plots }\end{array}$} & \multicolumn{2}{|c|}{$\begin{array}{l}\text { Dissimilarity (\%) } \\
\text { among treatments }\end{array}$} & $\mathrm{p}$ \\
\hline \multicolumn{6}{|l|}{ Mud } \\
\hline \multirow[t]{3}{*}{ Site 1} & C & 32 & PC vs C & 41 & \\
\hline & PC & 47 & C vs W & 37 & $<0.05$ \\
\hline & W & 32 & $\mathrm{PC}$ vs $\mathrm{W}$ & 42 & \\
\hline \multirow[t]{3}{*}{ Site 2} & $\mathrm{C}$ & 47 & $\mathrm{PC}$ vs $\mathrm{C}$ & 45 & \\
\hline & PC & 50 & C vs W & 43 & \\
\hline & W & 40 & PC vs W & 48 & \\
\hline \multirow[t]{3}{*}{ Site 3} & $\mathrm{C}$ & 73 & PC vs C & 67 & \\
\hline & PC & 62 & C vs W & 68 & \\
\hline & W & 53 & PC vs W & 59 & \\
\hline \multicolumn{6}{|l|}{ Sand } \\
\hline \multirow[t]{3}{*}{ Site 4} & $\mathrm{C}$ & 26 & PC vs C & 32 & $<0.05$ \\
\hline & PC & 28 & C vs W & 35 & $<0.05$ \\
\hline & W & 29 & PC vs W & 29 & \\
\hline \multirow[t]{3}{*}{ Site 5} & $\mathrm{C}$ & 27 & $\mathrm{PC}$ vs $\mathrm{C}$ & 43 & \\
\hline & PC & 45 & C vs W & 40 & $<0.05$ \\
\hline & W & 42 & PC vs W & 47 & \\
\hline
\end{tabular}
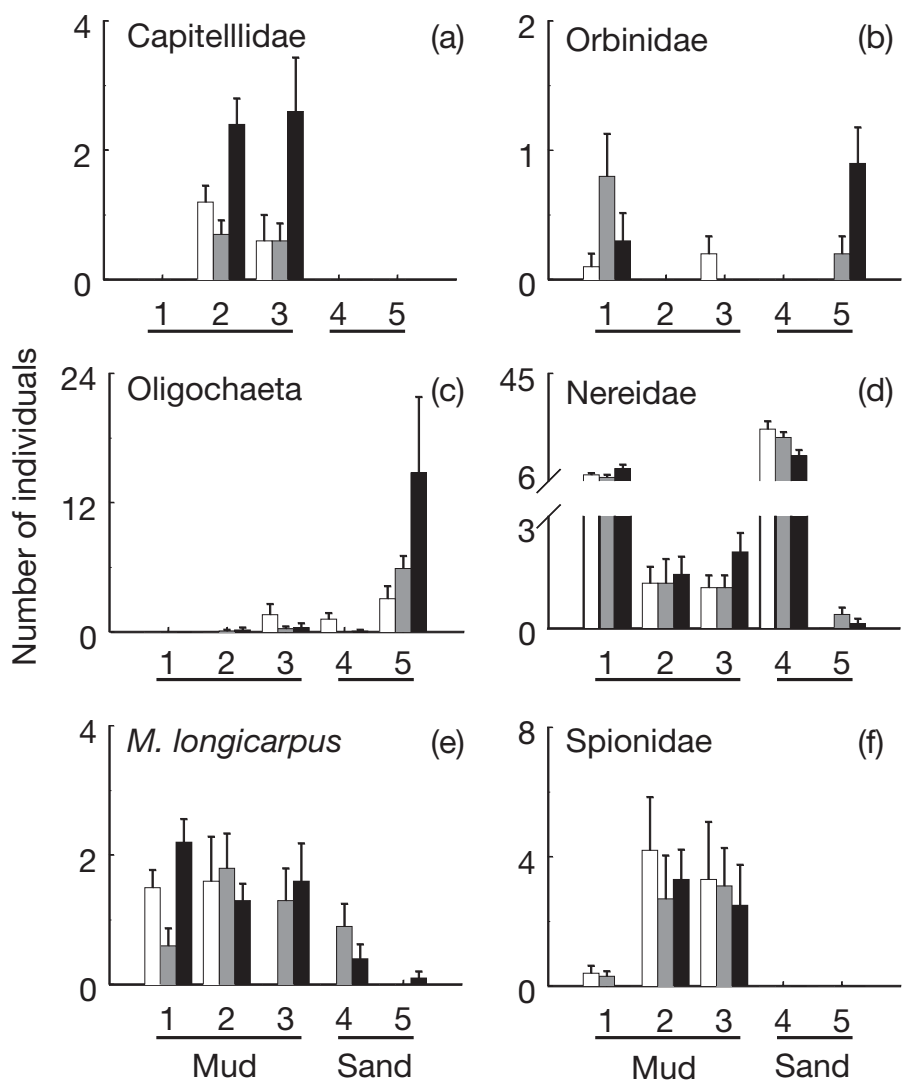

(c)

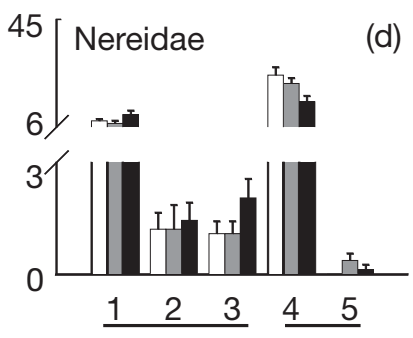

(e)

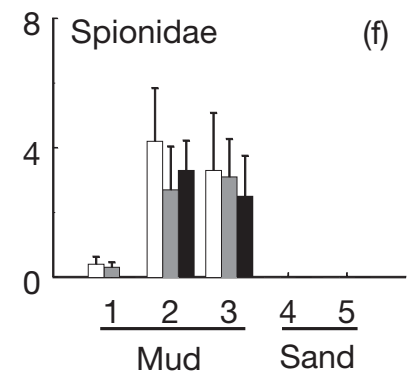

Fig. 4. Mean $( \pm \mathrm{SE} ; \mathrm{n}=10)$ number of animals in experimental treatments (means from 2 replicate cores in each of the 5 plots). $\square$ : controls (C); $\square$ : disturbance controls (PC); and $\mathbf{\square}$ : addition of wrack (W)
The ordinations of data from assemblages (Fig. 3) demonstrated that there was really no pattern separating the plots with wrack from the others, except possibly in Site 4. In Site 4, there was no difference between the assemblages in plots with wrack and those in the disturbance controls. Both groups were, however, different from the controls (Fig. 3).

\section{Analyses of variance of selected taxa}

Taxa that were widespread or relatively abundant were analysed separately (see examples in Fig. 4 and Table 3). As an example of a group showing a clear response to increased nutrients, in sites where they occurred, Capitellidae were about 3 times more abundant in treatments with wrack than in controls (Fig. 4a). In the corresponding analysis, there was therefore a significantly large interaction between treatments and sites (Table 3a). For Sites 2 and 3, multiple comparisons demonstrated significantly larger numbers $(p<0.05)$ in treatments with wrack than controls $(\mathrm{W}>\mathrm{PC}=\mathrm{C})$.

Orbinid and Oligochaete worms showed significant increases in plots with wrack in the sandy Site 5 , but not in other sites where they were present (Fig. 4b,c). The analyses for Orbinidae had the same pattern of significant terms as shown for Capitellidae (Table 3a). Oligochaeta at Site 5 showed larger abundances in $\mathrm{W}$ and $\mathrm{PC}(\mathrm{W}=\mathrm{PC}>\mathrm{C})$.

Nereidae showed a tendency for greater numbers in plots with wrack in the 3 muddy sites (Fig. 4d). The differences were not significant (because there were significant differences among plots; Plots [Treatment $\times$ Site] in Table 3, Nereidae). The greater abundance in $\mathrm{W}$ plots than in controls was, however, more frequent than would be expected by chance (Anderson's test, $\left.Q^{2}=11.0, \mathrm{p}<0.05\right)$; therefore, the trend was probably due to the experimental addition of nutrients.

Other taxa (the gastropod Polinices sp., the bivalve Mysella sp., the worms Nephtydae and Spionidae, and the amphipods Gammaridae and Urohaustoridae) simply showed spatial variation at different scales - among sites and among plots - with no influence of the different treatments. As an example, spionid worms are illustrated in Fig. $4 \mathrm{f}$ and Table 3. In some muddy sites, some of these species, such as nephtyid worms and Mysella sp., were more abundant where wrack was added, but no pattern was statistically significant (the analysis for Nephtydae is shown in Table $3 c_{\text {; }}$ there were differences in abundances among sites, but no significant effects of treatments). 
Table 3. ANOVAs of mean numbers of some representative taxa at the end of

\begin{tabular}{|c|c|c|c|c|c|c|c|}
\hline \multirow[t]{2}{*}{ Source of variation } & \multirow[b]{2}{*}{ df } & \multicolumn{3}{|c|}{ Capitellidae } & \multicolumn{3}{|c|}{ Nereidae } \\
\hline & & MS & $F$ & $\mathrm{p}$ & MS & $F$ & $\mathrm{p}$ \\
\hline $\mathrm{T}$ & 2 & 1.043 & 2.42 & ns & 0.116 & 0.2 & ns \\
\hline $\mathrm{S}$ & 4 & 4.138 & 26.98 & $<0.001$ & 59.006 & 178.43 & $<0.00$ \\
\hline $\mathrm{T} \times \mathrm{S}$ & 8 & 0.431 & 2.81 & $<0.01$ & 0.586 & 1.77 & ns \\
\hline $\mathrm{P}(\mathrm{T} \times \mathrm{S})$ & 60 & 0.153 & 1.76 & $<0.01$ & 0.331 & 1.61 & $<0.05$ \\
\hline Residual & 75 & 0.083 & & & 0.206 & & \\
\hline \multirow[t]{2}{*}{ Source of variation } & & \multicolumn{3}{|c|}{ Nephtydae } & \multicolumn{3}{|c|}{ Spionidae } \\
\hline & $\mathrm{df}$ & MS & $F$ & $\mathrm{p}$ & MS & $F$ & $\mathrm{p}$ \\
\hline $\mathrm{T}$ & 2 & 0.001 & 0.00 & ns & 0.031 & 0.15 & $\mathrm{~ns}$ \\
\hline $\mathrm{S}$ & 4 & 5.4874 & 50.90 & $<0.001$ & 7.957 & 13.03 & $<0.00$ \\
\hline $\mathrm{T} \times \mathrm{S}^{\mathrm{a}}$ & 8 & 0.024 & & & 0.205 & 0.34 & ns \\
\hline $\mathrm{P}(\mathrm{T} \times \mathrm{S})$ & 60 & 0.119 & & & 0.611 & 2.63 & $<0.00$ \\
\hline Residual & 75 & 0.128 & & & 0.232 & & \\
\hline Pooled $^{a}$ & 68 & 0.108 & 0.841 & ns & & & \\
\hline
\end{tabular}
the experiment (pooling as in Table 1 footnote)

\section{DISCUSSION}

\section{Total $\mathrm{N}$ and $\mathrm{OC}$}

The amounts of $\mathrm{N}$ and $\mathrm{OC}$ in all the treatments were in the range of natural variability found in many estuaries (Heip et al. 1995), and increases in the content of $\mathrm{OC}$ and $\mathrm{N}$ by burial of wrack were variable and sporadic. The composition of nutrients $(\mathrm{N}, \mathrm{P}$, and C) in detritus varies among plants (Enriquez et al. 1993), so influences of detrital material will vary both spatially and temporally. Bacterial activity is also variable, and therefore the rates of decomposition of specific plants (seaweeds, seagrasses, leaves of terrestrial trees) can vary from a few weeks to months, as has been deter-

The only other pattern of relevance to the hypotheses concerned the soldier crab Mictyris longicarpus. There was no pattern of differences in the mean abundances of crabs among treatments. The variability between replicate cores in experimental plots did, however, vary among treatments (Table 4). There was greater variability in plots with wrack or disturbance controls than in the controls $(\mathrm{W}, \mathrm{PC}>\mathrm{C}$ in multiple comparisons; $\mathrm{p}<0.05$ ). This was therefore a response to the disturbance of sediments rather than the addition of wrack.

Table 4. Mictyris longicarpus. ANOVA in number of soldier crab in experimental treatments; variances were calculated from 2 replicate cores in each of 5 plots in each treatment, unless there were no crabs in a plot. See Table 1 for definitions. (a) Mean $( \pm \mathrm{SE})$ variance for each treatment (variances $\left.\times 10^{3}\right)$; $\mathrm{n}$ : number of plots for which variance between cores was calculated. (b) ANOVA; $\mathrm{T} \times \mathrm{S}$ was pooled $(\mathrm{p}>0.25)$ for tests of $\mathrm{T}$ and $\mathrm{S}$ in the muddy sites, Sites 1 and 2 (for which data were available for all treatments)

\begin{tabular}{|c|c|c|c|c|c|}
\hline (a) & \multicolumn{2}{|l|}{$\mathrm{PC}$} & $\mathrm{C}$ & \multicolumn{2}{|c|}{$\mathrm{W}$} \\
\hline \multicolumn{6}{|l|}{ Mud } \\
\hline Site 1 & \multicolumn{2}{|c|}{$89(20 ; \mathrm{n}=4)$} & $35(21 ; \mathrm{n}=5)$ & \multicolumn{2}{|c|}{$33(14 ; \mathrm{n}=5$} \\
\hline Site 2 & \multicolumn{2}{|c|}{$91(53 ; \mathrm{n}=4)$} & $5(3 ; n=4)$ & \multicolumn{2}{|c|}{$54(33 ; \mathrm{n}=5$} \\
\hline Site 3 & \multicolumn{2}{|c|}{$15(11 ; \mathrm{n}=4)$} & & \multicolumn{2}{|c|}{$68(57 ; \mathrm{n}=3$} \\
\hline \multicolumn{6}{|l|}{ Sand } \\
\hline Site 4 & \multirow{2}{*}{\multicolumn{3}{|c|}{$30(15 ; \mathrm{n}=3)$}} & \multirow{2}{*}{\multicolumn{2}{|c|}{$\begin{array}{c}35(10 ; \mathrm{n}=3 \\
0(0 ; \mathrm{n}=1)\end{array}$}} \\
\hline Site 5 & & & & & \\
\hline (b) Source & variation & $\mathrm{df}$ & MS & $F$ & $\mathrm{p}$ \\
\hline $\mathrm{T}$ & & 2 & 0.1731 & 3.94 & $<0.05$ \\
\hline $\mathrm{S}$ & & 1 & 0.0048 & 0.11 & ns \\
\hline $\mathrm{T} \times \mathrm{S}^{\mathrm{a}}$ & & 2 & 0.0003 & & \\
\hline Residual & & 18 & 0.0487 & & \\
\hline Pooled $^{\mathrm{a}}$ & & 20 & 0.0439 & & \\
\hline
\end{tabular}

mined in both the laboratory and the field (Harrison \& Mann 1975, Pellikaan 1984, Harrison 1989, Inglis 1989, Peduzzi \& Herndl 1991, Enriquez et al. 1993). For example, Zostera marina has been shown to have great bacterial activity associated with decomposition after about $10 \mathrm{~d}$ of incubation in the laboratory (Pellikaan 1984) and to show increases in numbers of other saprophytic organisms, such as protozoa, within $40 \mathrm{~d}$ (Harrison \& Mann 1975). In the field, rates of degradation vary from 0.6 to $1.1 \%$ loss of total dry wt $\mathrm{d}^{-1}$, corresponding to about $40 \%$ of dry wt lost in about $50 \mathrm{~d}$ (Harrison 1989).

In the experiments described here, wrack was composed mainly of dead Zostera capricornii, which had been washed up about 1 mo before collection. Even though the wrack was already decomposing at the beginning of the experiment, nutrients were released during the experiment.

\section{Response of microalgae}

Chl a was not present in wrack analysed before burial. Additionally, phaeopigments did not increase in the plots where the wrack was added. Chl a was present in greater amounts in the plots to which wrack was added.

In estuaries, benthic microalgae can account for a large portion of the carbon budget of a detrital foodweb (Heip et al. 1995) and microphytobenthos can have a central role in moderating fluxes of carbon in coastal sediments (Herman et al. 2000, Middleburg et al. 2000). Nutrients (especially $N$ and P) have often been considered to limit the growth of benthic diatoms, and the ability of microalgae to exploit available $\mathrm{N}$ and 
P has been stressed in many studies (see Nilsson et al. 1991, Hillebrand et al. 2000). Mats of plant material could provide the nutrients necessary for proliferation of these microalgae. Levinton (1985) found that addition of Ulva rotundata in the absence of grazers (Ilyanassa sp. and Hydrobia totteni) could increase standing stocks of benthic diatoms after 2 to $3 \mathrm{wk}$. Sundback et al. (1996) reached similar conclusions. In their experiments, they hypothesised that the presence of algae on the surface would depress amounts of oxygen and would shade microalgae. Although they did not find a decrease in microalgae under the algal mats, they suggested that adaptation to increased shade and supply of nutrients might enable diatoms and other microbiota to coexist with a moderate amount of drift algae.

Here, diatoms and other microalgae are likely to be involved in the capture of nutrients, micronutrients and minerals other than $\mathrm{N}$ and $\mathrm{C}$, and to contribute to the maintenance of a pool of organic matter in the detritus. Furthermore, the increase of chl a (and therefore of microalgal biomass) 2 wk after burial of wrack was associated with an increase in nutrients.

\section{Response of macrofaunal assemblages}

Disturbance and the increase of nutrients did not make much difference to the composition and structure of the assemblages in muddy or sandy areas. Some taxa, however, were affected both by the availability of nutrients and by the disturbance of the wrack, while others did not show consistent patterns. Capitellidae and Orbinidae showed a clear increase in numbers in the plots in which wrack was added in the sites (mud and sand) and where they were already abundant. Nereidae, mostly represented by the species Australonereis ehlersi, were also more abundant where there was wrack, but only in the muddy sites. Moreover, the abundance of Oligochaeta and the micro-scale distribution of Mictyris longicarpus were affected by the disturbance created by the wrack.

In general, short-term positive responses (increases in abundance) have often been reported for species such as Capitella spp. and Nereis diversicolor under small patches of dead seaweeds on the surface of (Thrush 1986, Norkko \& Bonsdorff 1996a,b, Bolam et al. 2000) or buried in (Hull 1987) sediments. In most cases, these changes were associated with other changes in the composition of the assemblages. For example, Thrush (1986) found drastic changes of macrofaunal structure (abundance and composition of species) within 2 mo in subtidal muddy areas of Lough Hyne (Ireland) with Capitella capitata and Malacoceros fuliginosus increasing in abundance, but also with losses of rare species. Moreover, Norkko \& Bonsdorff $(1996 a, b)$ found negative effects of drifting algal mats on coastal macrobenthic assemblages, which shifted from suspension/surface feeders to burrowing detritivores and burrowing carnivores. They considered that only Nereis diversicolor and tubificid oligochaetes were able to benefit from such algal cover. Similar effects were also found in a sandflat (Drum Sand, Scotland) where the numbers of Capitella cf. capitata increased and numbers of all other species decreased (Bolam et al. 2000). In contrast, Hull (1987) found that most taxa in a mud-flat area in the Ythan estuary (Scotland) did not show any response to the addition of algal mats, but there was still a major positive effect on Capitella cf capitata and Nereis diversicolor, even when these mats were buried.

The response of oligochaetes contrasts with other studies, which have indicated that this taxon was always abundant in areas characterised by organic enrichment and reduced content of oxygen (Sardà et al. 1996). Oligochaetes are, in fact, able to exhibit opportunistic life-history traits and to tolerate hypoxia and sulphide (Norkko \& Bonsdorff 1996b). At the site of the present experiments, the addition of wrack might have modified the biochemistry of sediments in a similar direction to the modification induced by organic enrichment, thereby reducing the concentration of oxygen (Raffaelli et al. 1991, Norkko \& Bonsdorff 1996b, Holmquist 1997, Norkko et al. 2000).

The soldier crab Mictyris longicarpus increased in abundance in response to physical disturbance of the wrack in 1 muddy site, but not consistently in the other muddy sites, where it was similarly abundant. Rather, physical disturbance of wrack affected micro-scale distribution of the soldier crabs, which aggregated in small patches in the presence of buried mats (thus altering the variance of numbers per core). The distribution of burrowing crabs at small scales has been linked to the presence of stems, which may provide an anchor for burrowing especially in unconsolidated habitats (Bertness \& Miller 1984). Kelaher et al. (1998), however, found that in more consolidated substrata in mangrove forests, the crabs Heloecius cordiformis were more abundant in softer sediments. Two models could explain the burrowing behaviour of the soldier crab Mictyris longicarpus. First, within mats of wrack, there are structures, such as stems, which provided anchoring. Second, wrack is an obstacle to burrowing, and crabs can only burrow where the structure of the wrack is softer or less thick.

Among taxa, which did not show any response, amphipods such as Urohaustoridae and Gammaridae are largely affected by the presence of plant material on the surface of the sediment. Wrack can be either a refuge from predators and food (Inglis 1989, Colombini 
et al. 2000) or an obstacle to the settlement and recruitment of larvae (Hull 1987, Raffaelli et al. 1991). When algae disappear from the surface, rapid recolonisation (Ford et al. 1999), or no effect (Hull 1987) as in this study, have been found; therefore, responses are variable and, as yet, unpredictable.

Moreover, Mysella sp. and spionids also did not show any pattern. Other bivalves like Macoma baltica have shown mixed responses in different studies; increasing, decreasing or not changing under superficial (Norkko \& Bonsdorff 1996b) or buried algal mats (Hull 1987), depending on the degree to which the sediment became reduced (Hull 1987). Spionids like Pygospio elegans and Streblospio benedicti, although generally considered to show opportunistic behaviour, sometimes are not affected by organic enrichment (Bridges et al. 1994) or they show a negative response to the presence of mats (Norkko \& Bonsdorff 1996a, Bolam et al. 2000).

Reproduction, larval settlement or recruitment can be also stimulated by an increase in food (Hull 1987, Raffaelli et al. 1991, Ford et al. 1999, Bolam et al. 2000). In the short term, in small patches of mats, as in this study, the positive response of these animals could be related to the movements of adults (Norkko \& Bonsdorff 1996a) towards the patches of wrack, which can be more suitable micro-habitats for some species (oligochaetes) and constitute a source of food, especially for capitellids, nereids and orbinids.

Many nereid worms are known to be omnivorous or to feed on diatoms and macroalgal debris (Fauchald \& Jumars 1979, Smith et al. 1996) as well as to stimulate the mineralisation of the old fraction of different species of dead plants, including Zostera marina (Kristensen et al. 1992, Olivier et al. 1996). Orbinidae and Capitellidae are sub-surface deposit feeders (Fauchald \& Jumars 1979), which can easily feed on sediment modified by the wrack. Moreover, surface deposit feeders are not bulk ingestors of surface sediments, but rather they modify their behaviour and can choose to feed on enriched sediments at small spatial scales (Kihslinger \& Woodin 2000). Therefore, plant detritus under the sediment would attract these animals either by directly providing food or by enhancing the growth of other types of food.

Few studies have directly addressed the response to disturbances of organisms in muddy and sandy habitats. Populations living in organic-rich sediments may be capable of exploiting sudden resources of food and resisting hypoxic conditions (Pearson \& Rosenberg 1978, Lopez \& Levinton 1987). In the present study, Nereidae (mostly Australonereis ehlersi) were found in both mud and sand, but showed no responses in sand. This was also in agreement with laboratory experiments, where Nereis diversicolor have shown a differ- ent ability to mineralise $\mathrm{C}$ and $\mathrm{N}$ in mud as compared to sand (Hansen \& Kristensen 1998). This suggests that different populations of nereid worms could respond differently to additions of organic matter.

The effect of a disturbance can vary depending on its severity. Increasing the time of exposure, and the size of patches of wrack could cause changes in the response of the organisms. At low levels of stress, a disturbance could contribute to an increase in complexity of the habitat (bare patches and weed patches) and enhance heterogeneity of assemblages (Norkko \& Bonsdorff 1996b). Here, the small patches used and the short period of time could account for a small level of disturbance. Increasing the time of exposure and the sizes of the patches could cause more marked and, probably, negative effects.

Furthermore, the characteristics of resilience, inertia and stability of populations of the organisms can determine the type of response. In this study, all the sites where these experiments were done, although characterised by different organic loading, are affected by repeated input of wrack during the year. Together with the small severity of disturbance, the presence of a fauna characteristic of organic-enriched sediments and frequently affected by the deposition of wrack may be among the reasons why only minor changes in assemblages and positive effects in some taxa were observed, rather than major changes in assemblages and differences between mud and sand, which only occurred for nereids.

\section{CONCLUSIONS}

In this study, the effect of wrack due to its disturbing and creating a different structure in sediments was clearly differentiated from an effect due to the increase of nutrients by the use of carefully designed controls. There have been few studies which have taken disturbance itself into account and have therefore included appropriate controls in simulating the addition of wrack (Vetter 1996). Here, we did not have resources to include a completely undisturbed control, but disturbance of sediment was very small. In other experiments in local intertidal sediments (Lindegarth \& Underwood 2002), much greater disturbance of sediments did not affect macrofaunal assemblages. It would, however, be better to have included untouched controls.

As shown in this study, nutrients can be released from the wrack and are likely to be used by microphytobenthos, which may play a major role in the flux of carbon and nutrient in the sediments. Release of nutrients and wrack itself may also represent a direct or indirect source of food for some invertebrates 
(Capitellidae, Orbinidae and Nereidae) and physical disturbance, which is considered to be important when mats are stranded on the surface, is still important for some taxa (Oligochaeta and Mictyris longicarpus) when mats are buried. Nevertheless, although burial of aged plant material in small patches can contribute to the spatial variability of these macrofaunal assemblages, it does not represent a major source of variation. More wrack and longer periods of burial would probably be necessary before wrack causes changes in the structure of assemblages.

Acknowledgements. We thank Gee Chapman for her help in the early phase of this project. We also thank P. Barnes, A. Grigaliunas, K. Mills, G. Kaplan and M. Wirth for their work in the field and G. Ross for his help in finding the sites for the experiment. P. Honkoop assisted with analyses of C and N. T. Lasiak read an early draft of the manuscript, and comments of anonymous referees were helpful. The work was funded by the Australian Research Council through the Centre for Research on Ecological Impact of Coastal Cities. F.R. was sponsored by the Department of Scienze dell'Uomo e dell' Ambiente (University of Pisa, Italy).

\section{LITERATURE CITED}

Anderson MJ (2001) New method for non-parametric multivariate analysis of variance. Aust J Ecol 26:32-46

Anderson RL (1959) Use of contingency tables in the analysis of consumer preference studies. Biometrics 15:582-590

Azovsky AI, Chertoprood MV, Kucheruk NV, Rybnikov PV, Sapozhnikov FV (2000) Fractal properties of spatial distribution of intertidal benthic communities. Mar Biol 136: 581-590

Baldwin AH, Mendelssohn IA (1998) Response of two oligohaline marsh communities to lethal and nonlethal disturbance. Oecologia 116:543-555

Bertness MD, Miller T (1984) The distribution and dynamics of Uca pugnax (Smith) burrows in a New England salt marsh. J Exp Mar Biol Ecol 83:211-237

Bolam SG, Fernandez TF, Read P, Raffaelli D (2000) Effects of macroalgal mats on intertidal sandflats: an experimental study. J Exp Mar Biol Ecol 249:123-137

Brewer JS, Levine JM, Bertness MD (1998) Interactive effects of elevation and burial with wrack on plant community structure in some Rhode Island salt marshes. J Ecol 86: 125-136

Bridges TS, Levin LA, Cabrera D, Plaia G (1994) Effects of sediment amended with sewage, algae or hydrocarbons on growth and reproduction in two opportunistic polychaetes. J Exp Mar Biol Ecol 177:99-119

Chapman MG, Underwood AJ, Skilleter GA (1995) Variability at different spatial scales between a subtidal assemblage exposed to the discharge of sewage and two control assemblages. J Exp Mar Biol Ecol 189:103-122

Clarke KR (1993) Non-parametric multivariate analyses of changes in community structure. Aust J Ecol 18:117-143

Colombini I, Aloia A, Fallaci M, Pezoli G, Chelazzi L (2000) Temporal and spatial use of stranded wrack by the macrofauna of a tropical sandy beach. Mar Biol 136:531-541

Dayton PK (1971) Competition, disturbance and community organization: the provision and subsequent utilization of space in a rocky intertidal community. Ecol Monogr 41: 351-389
Dizon RM, Yap HE (1999) Short-term responses of coral reef microphytobenthic communities to inorganic nutrient loading. Limnol Oceanogr 44:1259-1267

Enriquez S, Duarte CM, Sand-Jensen K (1993) Patterns in decomposition rates among photosynthetic organisms: the importance of detritus C:N:P content. Oecologia 94:457-471

Fauchald K, Jumars PA (1979) The diet of worms: a study of polychaete feeding guilds. Oceanogr Mar Biol Annu Rev $1: 193-284$

Ford RB, Thrush SF, Probert PK (1999) Macrobenthic colonisation of disturbances on an intertidal sandflat: the influence of season and buried algae. Mar Ecol Prog Ser 191: $163-174$

Hansen K, Kristensen E (1998) The impact of the polychaete Nereis diversicolor and enrichment with macroalgal (Chaetomorpha linum) detritus on benthic metabolism and nutrient dynamics in organic-poor and organic-rich sediment. J Exp Mar Biol Ecol 231:201-223

Harrison PG (1989) Detrital processing in seagrasses systems: a review of factors affecting decay rates, remineralisation and detritivory. Aquat Bot 23:263-288

Harrison PG, Mann KH (1975) Detritus formation from eelgrass (Zostera marina L.): the relative effects of fragmentation, leaching, and decay. Limnol Oceanogr 20:924-934

Hedges JI, Stern JH (1984) Carbon and nitrogen determinations of carbonate-containing solids. Limnol Oceanogr 29: $657-663$

Heip CHR, Goosen NK, Herman PMJ, Krokamp J, Middelburg JJ, Soetaert K (1995) Production and consumption of biological particles in temperate tidal estuaries. Oceanogr Mar Biol Annu Rev 33:1-149

Herman PMJ, Middelburg JJ, Widdows J, Lucas CH, Heip CHR (2000) Stable isotopes as trophic tracers: combining field sampling and manipulative labelling of food resources for macrobenthos. Mar Ecol Progr Ser 204:79-92

Hillebrand H, Worm B, Lotze HK (2000) Marine microbenthic community structure regulated by nitrogen loading and grazing pressure. Mar Ecol Progr Ser 204:27-38

Holmquist JG (1997) Disturbance and gap formation in a marine benthic mosaic: influence of shifting macroalgal patches on seagrass structure and mobile invertebrates. Mar Ecol Prog Ser 158:121-130

Hull SC (1987) Macroalgal mats and species abundance: a field experiment. Estuar Coast Shelf Sci 25:519-532

Inglis G (1989) The colonisation and degradation of stranded Macrocystis pyrifera (L.) C. Ag. by the macrofauna of a New Zealand sandy beach. J Exp Mar Biol Ecol 125: 203-217

Kelaher BP, Underwood AJ, Chapman MG (1998) Effect of boardwalks on the semaphore crab Heloecius cordiformis in temperate urban mangrove forests. J Exp Mar Biol Ecol 227:281-300

Kihslinger RL, Woodin SA (2000) Food patches and a surface deposit feeding spionid polychaete. Mar Ecol Prog Ser 201:233-239

Kristensen E, Andersen FO (1992) Effects of benthic macrofauna and temperature on degradation of macroalgal detritus: the fate of organic carbon. Limnol Oceanogr 37: 1404-1419

Levin SA, Paine RT (1974) Disturbance, patch formation, and community structure. Proc Natl Acad Sci USA 71: 2744-2747

Levinton JS (1985) Complex interactions of a deposit feeder with its resources: roles of density, a competitor, and detrital addition in the growth an survival of the mudsnail Hydrobia totteni. Mar Ecol Prog Ser 22:31-40

Levinton JS, Bianchi TS, Stewart S (1984) What is the role of 
particulate organic matter in benthic invertebrate nutrition? Bull Mar Sci 35:270-282

Lindegarth M, Underwood AJ (2002) A manipulative experiment to evaluate predicted changes in intertidal macrofaunal assemblages after contamination by heavy metals. J Exp Mar Biol Ecol 274(1):41-64

Lopez GR, Levinton JS (1987) Ecology of deposit-feeding animals in marine sediments. Q Rev Biol 62:235-260

Middelburg JJ, Barranguet C, Boschker TS, Herman PMJ, Moens T, Heip CHR (2000) The fate of intertidal microphytobenthos carbon: an in situ ${ }^{13} \mathrm{C}$-labelling study. Limnol Oceanogr 45:1224-1234

Nilsson P, Jonsson B, Swanberg IL, Sundback K (1991) Response of a marine shallow-water sediment system to an increased load of inorganic nutrients. Mar Ecol Prog Ser 71:275-290

Norkko A, Bonsdorff E (1996a) Population responses of coastal zoobenthos to stress induced by drifting algal mats. Mar Ecol Prog Ser 140:141-151

Norkko A, Bonsdorff E (1996b) Rapid zoobenthic community responses to accumulation of drifting algae. Mar Ecol Prog Ser 131:143-157

Norkko J, Bonsdorff E, Norkko A (2000) Drifting algal mats as an alternative habitat for benthic invertebrates: speciesspecific responses to a transient resource. J Exp Mar Biol Ecol 248:79-104

Olivier M, Desrosier G, Caron A, Retière C (1996) Juvenile growth of the polychaete Nereis virens feeding on a range of marine vascular and macroalgal plant sources. Mar Biol 125:693-699

Paine RT, Levin SA (1981) Intertidal landscapes: disturbance and the dynamics of pattern. Ecol Monogr 51:145-178

Pearson TH, Rosenberg R (1978) Macrobenthic succession in relation to organic enrichment pollution of the marine environment. Oceanogr Mar Biol Annu Rev 16:299-311

Peduzzi P, Herndl GJ (1991) Decomposition and significance of seagrass leaf litter (Cymodocea nodosa) for the microbial food web in coastal waters (Gulf of Trieste, Northern Adriatic Sea). Mar Ecol Prog Ser 71:163-174

Pellikaan GC (1984) Laboratory experiments on eelgrass (Zostera marina L.) decomposition. Neth J Sea Res 18: 360-383

Pickett STA, Kolasa J, Armesto JJ, Collins SL (1989) The ecological concept of disturbance and its expression at various hierarchical levels. Oikos 54:129-136

Plante-Cuny MR (1974) Evaluation par spectrophotometrie des teneurs en chlorophylle- $a$ fonctionnelle et en phaeopigments des substrats meubles marins. ORSTOM, Nosy-Be

Posey MH, Alphin TD, Cahoon L, Lindquist D, Becker ME (1999) Interactive effects of nutrient additions and predation on infaunal communities. Estuaries 22:785-792

Raffaelli DG, Limia J, Hull S, Pont S (1991) Interactions between the amphipod Corophium volutator and macroalgal mats on estuarine mudflats. J Mar Biol Assoc UK 71: 899-908

Raffaelli DG, Raven JA, Poole LJ (1998) Ecological impact of

Editorial responsibility: Roger Hughes (Contributing Editor), Bangor, Wales, UK green macroalgal blooms. Oceanogr Mar Biol Annu Rev 36:97-125

Renaud PE, Syster DA, Ambrose WG (1999) Recruitment patterns of continental shelf benthos off North Carolina, USA effects of sediment enrichment and impact on community structure. J Exp Mar Biol Ecol 237:89-106

Rice DL, Tenore KR (1981) Dynamics of carbon and nitrogen during the decomposition of detritus derived from estuarine macrophytes. Estuar Coast Shelf Sci 13:681-690

Sardà R, Valiela I, Foreman K (1996) Decadal shifts in a salt mash macroinfaunal community in response to sustained long-term experimental nutrient enrichment. J Exp Mar Biol Ecol 205:63-81

Smith D, Hughes RG, Cox EJ (1996) Predation by epipelic diatoms by the amphipod Corophium volutator and the polychaete Nereis diversicolor. Mar Ecol Prog Ser 145: $53-61$

Sousa WP (1984) The role of disturbance in natural communities. Annu Rev Ecol Syst 15:353-391

Sundback K, Nilsson P, Nilsson C, Jonsson B (1996) Balance between autotrophic and heterotrophic components and processes in microbenthic communities of sandy sediments: a field study. Estuar Coast Shelf Sci 43:689-506

Tenore KR, Hanson RB, McClain J, Maccubbin AE, Hodson RE (1984) Changes in composition and nutritional value to a benthic deposit feeder of decomposing detritus pools. Bull Mar Sci 35:299-311

Thrush SF (1986) The sublittoral macrobenthic community structure of an Irish sea-lough: effect of decomposing accumulations of seaweed. J Exp Mar Biol Ecol 96: $199-212$

Thrush SF (1991) Spatial patterns in soft-bottom communities. TREE 6:75-79

Underwood AJ (1989) The analysis of stress in natural populations. Biol J Linn Soc 37:51-78

Underwood AJ (1997) Experiments in ecology: their logical design and interpretation using analysis of variance. Cambridge University Press, Cambridge

Valiela I, Rietsma CS (1995) Disturbance of salt marsh vegetation by wrack mats in Great Sippewissett Marsh. Oecologia 102:106-112

Valiela I, McClelland J, Hauxwell J, Behr PJ, Hersh D, Foreman K (1997) Macroalgal blooms in shallow estuaries: controls and ecophysiological and ecosystem consequences. Limnol Oceanogr 42:1105-1118

Vetter EW (1996) Enrichment experiments in infaunal population cycles on a southern California sand plain: response of the leptostracan Nebalia daytoni and other infauna. Mar Ecol Prog Ser 137:83-93

Warwick RM, Clarke KR (1993) Increased variability as a symptom of stress in marine communities. J Exp Mar Biol Ecol 172:215-226

Webb DG (1996) Response of macro- and meiobenthos from a carbon-poor sand to phytodetrital sedimentation. J Exp Mar Biol Ecol 203:259-271

Winer BJ, Brown DR, Michels KM (1991) Statistical principles in experimental design, 3rd edn. McGraw-Hill, New York

Submitted: December 11, 2001; Accepted: March 11, 2002

Proofs received from author(s): September 6, 2002 